beck College. The title of professor emeritus in the University has been conferred on the following: Prof. A. J. Allmand, on his retirement from the Daniell chair of chemistry at King's College; Sir Cyril Burt, on his retirement from the chair of psychology at University College ; and Prof. R. O. Kapp, on his retirement from the Pender chair of electrical engineering at University College. The title of reader in physics in the University has been conferred on Dr. O. E. H. Klemperer in respect of the post held by him at the Imperial College of Science and Technology.

\section{University of Birmingham : Appointments}

THE following appointments in the University of Birmingham have been announced : Prof. A. Boyce Gibson, professor of philosophy in the University of Melbourne, to be professor of philosophy in succession to Prof. L. J. Russell, who is retiring; Dr. S. C. Redshaw to be professor of civil engineering in succession to Prof. C. Batho, who is retiring; E. B. Edney, lecturer in zoology, to be reader in entomology; D. A. Bell, lecturer in electrical engineering, to be reader in electromagnetism; W. Carnegie, of the Pametrada Research Station, Wallsend, J. W. Railly, of C. W. Parsons and Co., Ltd., and F. E. Kras, of the Northampton Polytechnic, lecturers in mechanical engineering; Dr. R. Schneider, lecturer in experimental therapeutics.

\section{The Night Sky in August}

New moon occurs on August 13d. 16h. 48m., U.T., and full moon on August 27d. 14h. 51m. The following conjunctions with the moon take place : August 11d. 15h., Venus 5 S.; August 15d. 18h., Mercury $2^{\circ}$ S.; August 15d. 20h., Saturn $1^{\circ}$ N.; August 19d. 04h., Mars $3^{\circ}$ N.; August 27d. 12h., Jupiter $1^{\circ} \mathrm{N}$. In addition to these conjunctions with the moon, Mercury is in conjunction with Regulus on August 1d. 11h., Mercury $0.5^{\circ}$ N., and on August 16d. 22h. Mercury is in conjunction with Saturn, Mercury $3.5^{\circ} \mathrm{S}$. Mercury sets less than an hour after the sun on August 1 and attains its greatest eastern elongation on August 21; the planet is too close to the sun for favourable observation during the greater portion of the month. Venus rises about two hours before the sun throughout August and is conspicuous during the early morning hours, more than nine-tenths of the illuminated disk being visible through the greater part of the month (stellar magnitude $-3 \cdot 3$ ). Mars sets at $22 \mathrm{~h}$. on August 1 and $20 \mathrm{~h} .40 \mathrm{~m}$. on August 31, and is drawing rather close to the sun after this for favourable observation. Jupiter rises soon after sunset and is visible through. out the night in the constellation of Aquarius ; the planet is in opposition on August 26. Saturn sets at 21h. $10 \mathrm{~m}$. on August 1 and is too close to the sun for favourable observation during most of the month. Occultations of stars brighter than magnitude 6 are as follows: August 7d. 03h. 41.5m., 23 Taur. $(D)$; August 30d. 23h. $48 \cdot 4 \mathrm{~m}$., \& Pisc. $(D)$; Aug. 3ld. 00h. $49 \cdot 1 \mathrm{~m} ., \varepsilon$ Pisc. $(R) . \quad D$ and $R$ refer to disappearance and reappearance respectively, and the latitude of Greenwich is assumed.

\section{Announcements}

Prof. F. C. Streward, professor of botany in the University of Rochester, New York, formerly lecturer in Birkbeck College, London, has been appointed a professor of botany in Cornell University as from September 30.
DR. S. A. Barker, of the University of Birmingham, has been appointed Mackinnon Research Student of the Royal Society. $\mathrm{He}$ will work on the enzymic synthesis of polysaccharides.

Mr. L. M. JACKMAN (University of Adelaide) has been elected to a Beit Fellowship for scientific research of the value of $£ 500$ per annum, tenable at the Imperial College of Science and Technology, for research in organic chemistry under the direction of Prof. R. P. Linstead.

Mr. D. G. GILLAM (University of Melbourne) has been awarded an Overseas Science Scholarship by the Royal Commission for the Exhibition of 1851, in place of Mr. L. M. Jackman, who has accepted a Beit Fellowship (see above). Mr. Gillam will carry out research in physical chemistry at the Royal Institute of Technology, Stockholm.

The Committee of the Privy Council for Agricultural Research and Nature Conservation has reappointed Mr. T. Dalling and Dr. Joseph F. Duncan to be members of the Agricultural Research Council for a further term, and have also appointed Prof. S. C. Harland to be a member in the vacancy caused by the retirement from the Council of Sir David Brunt.

Mr. Arthur Mason, formerly a textile consultant in London, has been elected an honorary life member of the Textile Institute.

$I_{T}$ is announced by the University of Leeds that Mr. A. F. Maloney has been appointed to the newly instituted post. of lecturer in neuropathology; and Mr. B. W. Wyke has been appointed lecturer in physiology. Messrs. Brotherton and Co., Ltd., have renewed for seven years their gift of $\mathfrak{1} 1,000$ a year for maintaining a research lecturer and research assistant in chemical engineering in the University.

The Society of Physical Chemistry proposes to organise annually a meeting of several days duration for the discussion of a specific topic. In 1951, the meeting will take place in May, and the topic will be "Transferts électroniques en solutions et aux électrodes". Titles of communications must be submitted before December 31, 1950, and the complete papers by February 15, 1951. Further information can be obtained from the Secretary, Dr. G. Emschwiller, École Supérieure de Physique et de Chimie, 10 rue Vauquelin, Paris $\left(5^{0}\right)$.

The ninth General Assembly of the International Union for Geodesy and Geophysics will be held in Brussels during August 21-September 1, 1951. The provisional programme includes a symposium on the study of the ocean bottom, and joint meetings of different sections to discuss the physics of the upper atmosphere and ionosphere; general circulation of the oceans and the atmosphere; movements of the earth's crust ; and nature of the earth's core

Tна New Zealand Council of Scientific and Indus. trial Research is offering a postgraduate seholarship to enable a British graduate in science or engineering to spend two years in the Dominion. Hitherto, New Zealand students have come to Britain; but it is believed that the natural resources and climatic conditions of New Zealand provide unusual opportunities which would appeal to an overseas student. Particulars can be obtained from the New Zealand Scientific Office, Africa House, Kingsway, London, W.C.2. 